\title{
PENGARUH PENERAPAN METODE PEMBELAJARAN RESITASI-DEBAT PADA MATA PELAJARAN FIQIH POKOK BAHASAN HUDUD TERHADAP KEMAMPUAN PRESENTASI SISWA KELAS XI DI MAN 2 BLITAR
}

\author{
Roidatun Nazihah ${ }^{1}$, Zainul Abidin ${ }^{2}$, Arafah Husna ${ }^{3}$ \\ Teknologi Pendidikan, Fakultas Ilmu Pendidikan, Universitas Negeri Malang, \\ Email : roydatun29@gmail.com
}

\begin{abstract}
Abstrak
Metode pembelajaran Resitasi-Debat dalam penelitian ini merupakan penggabungan dari 2 metode yang berbeda. Berdasarkan hasil wawancara dan hasil observasi permasalah yang diperoleh yaitu kurangnya penguasaan materi pembelajaran fiqih dan kurangnya keaktifan siswa dalam mengikuti pembelajaran tersebut khususnya berkomunikasi secara lisan. Penelitian ini bertujuan untuk mengetahui keterlaksanaan penerapan metode resitasi-debat dalam upaya meningkatan kemampuan presentasi siswa. Dalam penelitian ini mengambil materi Hudud sub bab Mencuri dan minum khamr pada mata pelajaran Fiqih. Desain penelitian yang digunakan adalah desain penelitian Pra-eksperimen, One Shot Case Study. Metode pengumpulan data yang digunakan adalah teknik Observasi dengan lembar pengamatan. Teknik analisis data menggunakan skor persentase untuk mengetahui perbedaan pada kelas eksperimen setelah diberiperlakuan. Hasil Analisis data yang diketahui dari hasil observasi di kelas eksperimen dalam proses penerapan metode resitasi debat diperoleh nilai rata-rata 84,5\%. Maka dari itu dapat termasuk dalam kriteria baik sekali. Sedangkan pada kelas control dalam proses pembelajaran diperoleh nilai rata-rata 69,1\% termasuk dalam kriteria cukup. Kesimpulan penelitian ini menunjukkan bahwa perlakuan dengan menerapkan metode resitasi-debat mempengaruhi kemampuan prsentasi siswa secara signifikan dibandingkan dengan yang menggunakan pembelajaran ceramah dan diskusi pada proses pembelajaran Fiqih, pokok bahasan hudud kelas XI di MAN 2 Blitar.
\end{abstract}

Kata kunci : Metode, Resitasi, Debat, Fiqih, Presentasi

\section{PENDAHULUAN}

Pembelajaran pada hakekatnya yakni suatu proses interaksi antara siswa dengan lingkungannya, hingga kemudian terjadi perubahan sikap ke arah lebih baik. Selama proses pembelajaran, guru mempunyai tugas paling utama yakni mengkondisikan lingkungan belajar supaya mendukung terciptanya perubahan sikap bagi siswa (E.Mulyasa,2003). Keterlaksanaan proses pembelajaran tidak terbebas dari komponen-komponen yang ada didalamnya. Komponen pendidikan merupakan bagian dari suatu sistem proses pendidikan yang menetapkan berhasil atau tidaknya proses pendidikan (Slameto,2010). Komponen-komponen yang mempengaruhi pembelajaran yaitu antara lain peserta didik, guru, tujuan, materi, media, evaluasi dan metode.

Metode pembelajaran bisa dimaknai sebagai cara yang dimanfaatkan untuk mengaplikasikan rencana yang telah tersusun ke dalam bentuk kegiatan nyata serta praktis untuk memperoleh tujuan pembelajaran. Sudjana (2005: 76) beranggapan bahwa metode ialah perencanaan secara menyeluruh untuk mengemukakan materi pembelajaran bahasa secara teratur, tidak terdapat satu bagian yang bertolak belakang, serta semuanya berdasar pada suatu pendekatan tertentu. Metode pembelajaran yakni sebuah cara yang berbeda untuk 
mendapatkan hasil pembelajaran yang berbeda dibawah kondisi yang berbeda. Hal itu berarti dalam memilih metode pembelajaran perlu disesuaikan dengan kondisi pembelajaran dan hasil pembelajaran yang ingin dicapai (I Nyoman S Degeng : 2013).

Ketepatan guru dalam memilih metode pembelajaran yang sesuai memiliki pengaruh besar dalam proses maupun hasil pembelajaran. Kesalahan pemilihan metode atau salah dalam melaksanakannya juga dapat berakibat pada proses dan hasil pembelajaran. Seringkali pembelajaran menjadi membosankan dan tidak menarik karena pemilihan metode pembelajaran yang kurang tepat sehingga hasil belajarnya pun kurang maksimal.

Berdasarkan hasil observasi di MAN 2 Blitar pada saat pembelajaran fiqih, khususnya pada pokok bahasan Hudud menunjukkan bahwa sebagian besar siswa mempunyai penguasaan materi yang rendah dan kurang berperan serta aktif dalam pembelajaran. Selama kegiatan pembelajaran berlangsung suasana kelas begitu sunyi. Pada saat pembelajaran berlangsung siswa kurang aktif memberi tanggapan maupun bertanya bahkan kurang berani dalam menjawab pertanyaan guru.

Sebanyak $89 \%$ siswa tidak berani memberi tanggapan atau memberi tambahan ketika ada siswa lain yang salah menjawab pertanyaan. Namun, ketika Guru memberikan kesempatan kepada siswa untuk menjelaskan kembali terkait materi yang telah dibaca sebelumnya, tetapi hampir 90\% siswa menjelaskan dengan masih membaca buku serta tidak dengan bahasanya sendiri. Hal ini membuktikan peguasaan materi siswa yang masih rendah. Dapat disimpulkan bahwa pemasalahan yang terjadi pada pembelajaran fiqih di kelas XI, khususnya pada kelas XI Agama adalah kurangnya penguasaan materi pembelajaran fiqih dan rendahnya keaktifan siswa dalam mengikuti proses pembelajaran tersebut khususnya berkomunikasi secara lisan.

Berdasarkan hasil dari wawancara dan observasi tersebut maka diperoleh salah satu upaya yang dapat mengatasi permasalah, yaitu penguasaan materi dan keaktifan komunikasi lisan siswa adalah dengan menerapkan metode debat dan menggabungkannya dengan metode resitasi sebagai upaya stimulus siswa dalam menggali konsep, materi, informasi dan pengetahuan dari sumber belajar lain terkait materi fiqih yang dapat mendukung dalam penerapan metode debat. Menurut Widiastuti (2014 : 154) menyatakan bahwa di dalam metode debat banyak ketrampilan yang dapat dilatihkan dalam proses pelaksanaannya, antara lain kemampuan berkomunikasi dan mengkomunikasikan gagasannya kepada orang lain. Dengan menggunakan metode debat dapat member keleluasaan seluruh siswa untuk mencoba berkomunikasi lisan. Mereka dapat saling berargumentasi antara siswa dengan berdasarkan logika dan topic pembicaraan. Berdasarkan perpaduan metode diatas, diharapkan dapat mengatasi permasalahanpermasalahan dalam pembelajaran fiqih pada kelas XI Agama di MAN 2 Blitar.

Untuk mengetahui keberhasilan dari penerapan kedua metode dalam mengatasi masalah-masalah tersebut, maka peneliti memilih kegiatan presentasi sebagai langkah selanjutnya. Dalam presentasi dapat dilihat siswa dengan penguasaan materi tinggi serta dapat dilihat pula siswa yang aktif, yang nampak pada kegiatan presentasi yaitu tanya jawab, menanggapi, dan sebagainya. 
Dari uraian diatas, peneliti tertarik untuk meneliti tentang "Pengaruh Penerapan Metode Pembelajaran ResitasiDebat Pada Mata Pelajaran Fiqih Pokok Bahasan Hudud Terhadap Kemampuan Presentasi Siswa Kelas XI"

\section{METODE}

Penelitian ini menggunakan pendekatan kuantitatif, dimana data penelitian berupa angka-angkadan analisis menggunakan statistik. Dalam penelitian inimenggunakan Pre-Experiment. Desain penelitian yang digunakan pada penelitian ini adalah Studi Kasus Bentuk Tunggal (One-shot Case Study), yakni terdapat suatu kelompok yang diberikan treatment (perlakuan) dan seterusnya diobservasi hasilnya. Treatment sebagai variabel bebas dan hasil sebagai variabel terikat. Dalam penerapan desain ini subjek diberikan beberapa perlakuan.

Secara sistematis bagan penelitian yakni sebagai berikut

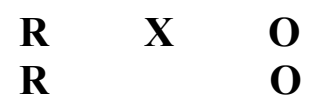

R : Kelompok eksperimen dan kontrol kelas XI Agama

X : Treatment yang diberikan

O : Observasi

VARIABEL

Variabel ialah objek penelitian atau hal yang menjadi titik fokus penelitian. Menurut Arikunto (2010:159), variabel adalalah gejala yang bervariasi, yang menajdi objek penelitian. Penelitian ini terdapat dua variabel yakni variabel bebas dan variabel terikat. Pada penelitian ini yang menjadi variabel bebas dan variabel terikat adalah :

a. Variabel bebas
Variabel yang mempengaruhi atau menjadi sebab perubahannya atau timbulnya variabel dependen (terikat). Dalam penelitian ini, variabel bebas yang dimaksud adalah metode Resitasi -Debat.

b. Variabel terikat

Variabel yang dipengaruhi atau yang menjadi akibat, karena adanya variabel bebas. Dalam penelitian ini, variabel terikat yang dimaksud adalah kemampuan presentasi siswa kelas XI pada mata pelajaran Fiqih di MAN 2 Blitar.

\section{METODE PENGUMPULAN DATA}

Dalam penelitian ini metode yang diterapkan oleh peneliti sebagai berikut :

1. Metode wawancara

Wawancara atau interview adalah mengumpulkan keterangan dengan cara mengajukan beberapa pertanyaan dengan cara lisan untuk dijawab secara lisan pula. Wawancara dilakukan dengan maksud memperoleh data ataupun informasi yang lengkap dan valid.

2. Metode dokumentasi

Metode dokumentasi digunakan untuk mengetahui nama, jumlah siswa dan suasana kelas yang berlangsung

3. Metode Observasi

Metode ini dimaknai sebagai pengamatan serta pancatatan secara runtut terhadap gejala yang terlihat pada objek penelitian.

Metode observasi dilakukan untuk melihat dan mengukur kemampuan presentasi siswa dengan menggunakan lembar observasi.

\section{HASIL DAN PEMBAHASAN}

a. Analisis Validitas

Sebelum menganalisis data terlebih dahulu menganalisis instrument uji coba 
yang sudah diujicobakan pada kelas yang pernah memperoleh materi hudud yaitu kelas XI MIA 1 MAN 2 Blitar. Penelitian ini menggunakan instrument yang berupa lembar observasi (pengamatan) kemampuan presentasi siswa, yang terdiri dari 11 aspek dengan 3 skor penilaian. Agar dapat digunakan sebagai instrument pada kelompok eksperimen dan kelompok kontrol maka terlebih dahulu dilakukan uji validitas dan reliabilitas. Hasil analisis butir pernyataan adalah sebagai berikut :

a. Analisis Validitas

Analisis validitas dimanfaatkan untuk melihat valid tidaknya item aspek. Item aspek yang tidak lolos uji validitas dibuang dan tidak digunakan, sebaliknya item yang lolos uji coba dimanfaatkan untuk penilaian akhir pada kelas eksperimen dan kelas kontrol pada materi hudud.

Berdasarkan uji coba instrumen yang telah dilaksanakan dengan jumlah peserta uji coba, $\mathrm{N}=36$ dan taraf signifikan 5\% didapat $r_{\text {tabel }}=0,329$, jadi item aspek dikatakan valid jika $r_{\text {hitung }}>0,329$ ( $r_{\text {hitung }}$ lebih besar dari 0,329). Berdasarkan perhitungan uji coba instrumen yang berjumlah 11 aspek diperoleh 8 aspek yang valid dan 3 aspek yang tidak valid. Maka aspek yang tidak valid akan dihapus dan tidak dimanfaatkan lagi untuk mengambil data pada kelompok control dan kelompok eksperimen.

\section{b. Analisis Reliabilitas}

Butir aspek yang berhasil lolos uji validitas, kemudian dilakukan uji reliabilitas pada instrument tersebut. Uji relibilitas digunakan untuk mengetahui tingkat kestabilan jawaban instrumen. Hasil perhitungan koefisien reliabilitas 8 aspek instrument diperoleh $\mathrm{r}_{\text {hitung }}=0,487$. Apabila $r_{\text {hitung }}$ lebih besar dari $r_{\text {tabel }}\left(r_{h}>r_{t}\right)$ maka butir instrument tersebut reliable, tetapi sebaliknya bila $\mathrm{r}_{\text {hitung }}$ lebih kecil dari $\mathrm{r}_{\text {tabel }}$ $\left(\mathrm{r}_{\mathrm{h}}<\mathrm{r}_{\mathrm{t}}\right)$ maka instrument tersebut tidak reliable. (Nidjo Sandjojo, 2011 :152-153). Maka dapat disimpulkan berdasarkan $\mathrm{r}_{\text {tabel }}$ dengan subyek $\mathrm{N}=36$ taraf signifikansi 5\% diperoleh $r_{\text {hitung }}$ lebih besar dari $r_{\text {tabel }}(0,487$ $>0,329)$. Maka data instrument adalah reliable (dapat dipercaya).

Dari pelaksanaan penelitian yang telah dilaksanakan pada kedua kelompok yaitu kelompok control dan kelompok eksperimen, pada kelompok control pembelajaran dilaksanakan secara konvensional yaitu dengan metode ceramah serta Tanya jawab diperoleh hasil rata-rata skor 69,1 dengan rincian 3 siswa dalam kategori baik sekali, 6 siswa dalam kategori baik, 6 siswa dalam kategori cukup dan 4 siswa dalam kategori kurang. Hasil rata-rata tersebut dapat dikategorikan bahwa kemampuan presentasi siswa termasuk cukup.

$\begin{array}{ccr}\text { Pada } & \text { kelompok } & \text { eksperimen } \\ \text { pembelajaran } & \text { dilakukan } & \text { dengan }\end{array}$ memanfaatkan metode gabungan resitasidebat diperoleh hasil rata-rata skor 84,5 dengan rincian 13 siswa dalam kategori baik sekali dan 6 siswa dalam kategori baik. Hasil rata-rata tersebut dapat dikategorikan bahwa kemampuan presentasi siswa termasuk baik sekali.

Setelah pemberian perlakuan yang berbeda pada kedua kelompok, maka perbedaan tingkat kemampuan presentasi siswa kelas XI agama mata pelajaran fiqih materi hudud bisa dibuktikan dengan penguasaan aspek-aspek kemampuan presentasi siswa. Pada kelompok control dengan metode konvensional terdapat beberapa aspek yang memperoleh skor sangat rendahya itu pada aspek penyajian materi dengan skor 6,3; aspek memberikan pendapat dengan skor 4,9; aspek 
menghargai pendapat dengan skor 6,3; aspek mengajukan pertanyaan dengan skor 4,7; dan aspek tingkat penguasaan topic dengan skor 5,8. Dari data tersebut diperoleh presentase rata-rata skor $62,2 \%$. Hasil tersebut termasuk dalam kriteria cukup. Sedangkan pada kelompok eksperimen ditemukan perbedaan yang signifikan pada aspek yang rendah di kelompok kontrol, yaitu aspek penyajian materi dengan skor 7,5; aspek memberikan pendapat dengan skor 7,2; aspek menghargai pendapat 7,9 ; aspek mengajukan pertanyaan 7,7 ; tingkat penguasaan topik dengan skor 7,2. Dari data tersebut diperoleh hasil presentase rata-rata skor $76,2 \%$. Hasil tersebut termasuk dalam criteria baik.

Berdasarkan hasil analisis data diatas bisa ditarik kesimpulan bahwa penerapan metode resitasi-debat mempengaruhi kemampuan presentasi siswa kelas XI Agama pada mata pelajaran fiqih materi hudud.

\section{PENUTUP}

dapat $\begin{gathered}\text { Penerapan metode resitasi debat } \\ \text { mempengaruhi kemampuan }\end{gathered}$ presentasi siswa kelas XI Agama pada mata pelajaran Fiqih materi hudud di MAN 2 Blitar. Melalui metode ini siswa diberikan stimulus untuk menguasai materi secara tidak langsung yaitu dengan metode resitasi atau pemberian tugas. Penugasan tersebut berupa sejumlah pertanyaan uraian yang harus dijawab oleh siswa secara kelompok dengan pembagian tugas masing-masing. Selanjutnya, pembahasan tugas tersebut diteruska nmelalui metode debat. Melalui metode debat siswa dituntut untuk ikut serta dan berperan aktif dalam proses pembelajaran. Metode debat dibagi menjadi
2 kelompok yaitu kelompok kontra dan kelompok pro.

Perbedaan perlakuan dalam proses pembelajaran menyebabkan perbedaan tingkat kemampuan presentasi siswa kelas XI Agama MAN 2 Blitar. Perbedaan dari kedua kelompok yaitu kelompok kontrol rata-rata aspek 6,22 dan kelompok eksperimen 7,62. Jumlah siswa pada masing-masing kelompok yaitu 19 orang diperoleh rata-rata jumlah skor kelompok control yaitu 69,1 sedangkan rata-rata jumlah skor kelompok eksperimen 84,5.

Berdasarkan temuan yang telah dijabarkan pada bagian sebelumnya, maka beberapa saran dapat dianjurkan, diantaranya Metode pembelajaran merupakan komponen yang mempengaruhi hasil belajar siswa, karena itu disarankan kepada guru untuk dapat memilih metode pembelajaran yang cocok sesuai dengan tujuan pembelajaran yang ingin dicapai, Dalam melaksanakan metode resitasi guru sebaiknya terlebih dahulu memilih jenis penugasan yang tepat, dan petunjuk pengerjaan yang jelas, serta waktu yang cukup sehingga siswa dapat melaksanakannya dengan maksimal, langkah-langkah penerapan metode debat sebaiknya disusun terlebih dahulu dengan menentukan tema dan topik bahan debat yang disesuaikan dengan bahan yang diajarkan.

\section{DAFTAR RUJUKAN}

Arikunto, Suharsimi. 2010. Prosedur Penelitian (Suatu Pendekatan Praktek). Jakarta : Rineka Cipta

Degeng, I Nyoman S. 2013. Ilmu Pembelajran : klasifikasi Variabel untuk pengembangan teori dan penelitian. Bandung : Kalam Hidup

Mulyasa, E.2003.Kurikulum berbasis kompetensi: konsep, karakteristik, 
dan implementasi. Bandung : PT Remaja Rosda Karya

Sandjojo, Nidjo.2011. Metode Analisis Jalur (Path Analysis) Dan Aplikasinya, Cetakan Pertama. Jakarta: Pustaka Sinar Harapan.

Slameto. 2010. Belajar \& Faktor-Faktor yang Mempengaruhinya. Jakarta: Rineka Cipta

Sudjana, Nana dan Ibrahim.2009. Penelitian Dan Penilaian Dan Penilaian Pendidikan. Bandung: Sinar Baru algesindo

Sularso, Yohanes.2014.Pengaruh Penerapan Metode Resitasi Terhadap Hasil Pembelajaran Mata Pelajaran IPS Bagi Peserta Didik. E-journal IKIP, vol 1 No. 1. http://e-journal.ikip- veteran.ac.id/index.php/dimensi/arti cle/view/254

Widarmana, I Gede Putu, dkk. 2015. Pengaruh Metode Debat Terhadap Kemampuan Berbicara Dalam Bahasa Inggris Ditinjau Dari Ekspektasi Karir Bahasa Inggris Pada Siswa Kelas Xii Sma N 1 Kerambitan. E- Journal Program Pascasarjana Universitas Pendidikan Ganesha, volume 6 No. 1 tahun 2015.https://media.neliti.com/media /publications/80450-ID-pengaruhmetode-debat-terhadapkemampuan.pdf, diakses tanggal 24 Mei 2018

Widiastuti, Hartati.2014.95 Strategi Pembelajaran. Jakarta :Indeks 